\title{
A Modern Pilgrim in Mecca and a Siege in Sanaa
}

John Byng Wavell

Reading, UK: Garnet Publishing, 2005. 349 pages.

It should be noted that the trespassing English pilgrim Arthur Wavell is definitely not postmodern; his "modern” account of a trip in disguise to Makkah and Madinah was originally published in 1912. The author revels in explaining how he pulled off the role of a Zanzibar Muslim on hajj, as though he is presenting a how-to guide for fellow swashbucklers. Previously, he had carried out intelligence work for the British Army in South Africa and, in 1906, settled on a farm near Mombasa, where he learned Arabic and met Muslims. He died at the young age of thirty-four while fighting in East Africa.

Wavell presents a riveting tale with a self-serving hubris that could easily be dismissed as a remake of Sir Richard Burton's earlier and more celebrated penetration of Makkah. But there is good reason to read this dated book, if only for the historical view of travel to Makkah near the end of the Ottoman caliphate. Wavell traveled from Damascus on the Hijaz railway the very year (1908) that it reached Makkah. His trip was made partly out of curiosity, no doubt fueled by the fact non-Muslims are forbidden to enter 
Makkah, and as a test for future travel in Arabia's interior (p. 28). However, he does give a detailed personal description (chapter 9) of the hajj in that year.

After his escapades in Arabia, replete with Bedouin robbers and pilgrimage con artists, he ventured on to Yemen and became embroiled in a 1911 local war in the capital Sanaa. Half of his narrative is given over to his problems in dealing with the Turkish bureaucracy in Yemen. This is interesting for the political details, but says virtually nothing of value about Zaydi Islam in Yemen.

Although he reflects an at-times-nauseating love of British self, the author is surprisingly sympathetic when talking about Muhammad ("a man of sound common-sense, personal bravery, and gentle disposition” [p. 11]). Indeed, he is as harsh on Christianity as he is on Islam: "The history of Islam is a record of bloodshed and debauchery, but not more so than that of Christendom. Fanatical religious sentiment has been the cause of much suffering and strife in the case of the former, but it is doubtful if a parallel for the treachery of St. Bartholomew's Eve or the cruelties of the Inquisition can be found in Moslem annals” (p. 21). He has harsher things to say about the local Bedouin, who "though brave, generous, and hospitable, they are treacherous and consider things allowable in war that are decidedly not “cricket”' (p. 59). This is surely no primer on Islam, but the grudging respect of a non-religious European who spent time with many kinds of Muslims is worth noting.

Much of the text is about politics, especially how the Turks were losing power in Arabia and how they, in the author's view, looked at Europe. It is hard not to regard him as a "spy," despite his constant plea that he was simply under the spell of a "lust for knowing," as Robert Irwin might say. Wavell is savvy and aware of local variations and the range of political opinions, but he is still an unrepentant Orientalist who insists that "what is true of the Turk in this respect is true of other Orientals, the difference being only in degree" (p. 183). Population estimates are given (some 30,000 for Madinah), and much attention is paid to soldiers and military strategy. He reflects on Muslim attitudes to the Ottoman sultanate, with the existence of a pan-Islamism under the Turkish sultan a possibility for Sunnis but "ex hypothesi impossible” for Shi`ahs (p. 20).

Wavell also delights in fellow rogues, as exemplified in his dialogue with a Turkish general who accused him of being an English spy:

"Your country wants more land, we all know that, and will take ours if it can. Good. All Governments are bad and one pack of thieves is no worse 
than another. Islam or Christianity - what does it matter? Fairy tales - as you know as well as I do ... The Prophet was a rogue, the sultan is a rogue and so is Mohammed Ali. They all do the best they can for themselves. I am a rogue myself," concluded his Excellency as he again refilled his glass, "and so are you.” (p. 183)

There is much trivia worth knowing in the text. For example: the ease of passing off Arabic due to the wide differences in existing Arabic dialects (p. 32), the Turkish love for the gramophone (p. 55), the claim that the entrance to Madinah is more jealously guarded than Makkah itself (p. 77), how Persians are perceived in Arabia (p. 89), the travails of a camel caravan (pp. 10009), finding dirty European postcards in a Makkan shop (p. 137), a description of Javanese Muslims (p. 139), Makkah's slave market (pp. 142-43), the impact of disease on pilgrims (pp. 154-55), sectarian arguments over sighting the new moon (pp. 159-60), the treatment of thieves in Makkah (p. 166), and the use of women's clothing as a disguise for escape (p. 204). It is unfortunate that the reprint does not contain the photographs found in the original.

Finally, he offers advice that, in hindsight, borders on prophecy. What else can be said about his tip after arriving in Yembu: "Any one starting a hotel here or in Jiddah would be sure of large profits" (p. 109). The profit from reading this highly opinionated text will not be large, but it will suffice as entertainment and historical interest.

Daniel Martin Varisco Chair, Department of Anthropology Hofstra University, Hempstead, New York 